\title{
既存戸建住宅の基礎の沈下・傾斜及びひび割れ等に関する実態調査 A STUDY OF SETTLEMENT, INCLINE AND CRACKING OF FOUNDATION FOR EXISTING DETACHED HOUSES
}

\author{
田村昌仁*, 伊奈 潔**, 藤井衛***, 川村政史****, 水谷羊介***** \\ Masahito TAMURA, Kiyoshi INA, Mamoru FUJII, Masashi KAWAMURA \\ and Yousuke MIZUTANI
}

\begin{abstract}
Floor incline, differential settlement and cracking of foundation in existing detached houses were investigated. The inspection was carried out, prior to neighboring constructions, to confirm the service life of basement. A total 864 houses in 113 areas on the soft ground in Tokyo metropolitan area was covered. The major findings are as follows.

1. Extent of differential settlement was generally improved in houses built with the current specification of the housing loan corporation but a 10 percent cases on the soft ground area exceeded the permissible limit of $25 \mathrm{~mm}$. This implies that the differential settlement cannot be eliminated solely by a basement construction specification.

2. Extent of floor incline depends on the measured section and showed 20 percent larger value than the measurements at each end of the floor. This maximum angle of gradient was controlled by the differential settlement rather than the foundation construction specification and may become less than $6 / 1000$ when the differential settlement less than $25 \mathrm{~mm}$.

3. Extent of column incline was approx. 2/1000 even without any floor incline. A floor incline less than $4 / 1000$ may be necessary to give a column incline less than $6 / 1000$.

4. No significant relation was found between basement cracking and differential settlement or angle of gradient. A foundation crack width exceeding the control value of $0.5 \mathrm{~mm}$ was found in a 20 percent of houses built with the revised specification.
\end{abstract}

Keywords : Detached house, Foundation, Differential settlement, Crack, Quality reservation, Flaw, Field survey 戸建住宅，基礎，不同沈下，ひびわれ，品質確保，瑕疵，現地調査

\section{1. まえがき}

2000 年の「住宅の品質確保の促進等に関寸る法律 (以下、品確法)」 の施行に伴い、木造住宅の基礎も含めて新筑住宅の構造耐力上主要な 部分の层疵担保期間を 10 年とする制度が確立した。地盤は構造耐力 上主要な部分ではないが、地盤に見合った適切な基礎であれば沈下障 害は生じないため、沈下障害は基礎に琚疪があるとみなされる可能性 があり、不同沈下をめぐる住宅紛争も增加している。圧密沈下などに よる沈下障害を考えると、瑕疪担保期間の持つ意味は大きい。床の傾 斜や基礎のひび割れ等が生じた場合、障害度に応じて瑕疵の可能性を 判断する定量的な目安 (休の傾斜角や基礎のひび割れ幅)が建設省 (現 国土交通省）告示第 1653 号で規定されたことを考慮すると、10 年 間の圧密沈下の可能性を考慮した基䃈設計が必要になっていると考 えなければならない。また、2002 年 8 月に既存住宅に対する住宅性 能表示制度 (任意の制度) が公布・施行され、住宅性能表示制度は新 築・既存を問わない全ての住宅を対象とした制度となった。既存住宅 に対する制度は、既存住宅の売買、リフォーム、維持管理等に関して 消費者の判断の目安となる情報の提供を目的としているが、この制度 の利用に際して、万一、不具合等のトラブルが生じた場合、新築住宅 と同様に紛争処理機関の利用が可能であり、裁判によらない迅速・公 平な処理も期待できるようになっている。
このように新築時のみならず既存住宅についても性能表示がなさ れるようになると、建築時の要求性能だけでなく、達成性能とその継 続性にも十分配慮した設計施工が今まで以上に必要であり、基礎に関 連する劣化や機能低下など、経年変化にも配慮した設計施工法を構築 しなければならない。耐用性の評価基準に関しては、前述の告示第 1653 号の規定のほか、性能表示制度とは別に既存住宅の珢疵などに 対する保証制度 (既存住宅保証制度) も設けられている。これらの評 価基準は、設計目標、瑕疵の可能性の判定、修復の必要性の判定など のための参考値として実務で用いられつつある。現状の評価基準の目 安值は、施工精度や測定誤差、沈下障害の実態調査や修復工法が採用 されている住宅の障害レベル、などを考慮して設定されていると考え られるが、目安值を超える可能性と基礎仕様や設計法の関倸について は必ずしも十分なデータが蓄積されていない。合理的な住宅基礎の設 計施工法を構築するためには、設計計算法だけでなく、基礎（地盤改 良を含む)の仕様や地盤条件などを考慮した実態調查に基づく設計施 工法の検証も重要である。そこで、今回は、第一段階の研究として、 既存住宅の実態調査結果を用いて耐用性に関する基礎資料を収集し、 不同沈下量や傾斜角およびひびわれ幅との関係を整理し、これら諸数 值と評価基準との関連性について考察を行うことにした。

なお、本来、上部構造にひび割れなどの損傷を発生させるのは変形

\footnotetext{
* 独建築研究所国際地震工学センタ- 上席研究員・工博

** 中央建鉄侏生中央技術研究所所長

*** 東海大学工学部建築学科 教授・工博

**** 日本大学生産工学部建築工学科 教授・博上: (工学)

***** 兼松日産農林(侏脑オテック事業部 博士(工学)
}

Building Research Institute, IISEE, Dr. Eng.

Director, Chuo Kentetsu Corporation Chuo Technical Research Center

Prof., Dept. of Architecture and Building of Engineering, Tokai Univ., Dr. Eng.

Prof., College of Industrial Technology, Nihon Univ., Dr. Eng.

Kanematsu-NNK Corporation, Geotech Div., Dr. Eng. 
角であるが、住宅においては傾斜角が大きいと居住性を損なうことに なるため本報では傾斜角を用いている。

\section{2. 実態調查データと分析方法}

2-1. 既存建物の実態調查データ

住宅に近接して行われる建設工事では、近接住宅について工事着手 前に表・1 に示す事前調査を行い、完了後にはこの資料をもとに工事 による影響の有無を判断する必要がある。これらの調查は影響の生じ や寸い軟弱地盤の地域で実施する事が多い。建設工事による障害の実 態については、すでに文献1) などで紹介しているが、ここでは外乱 要因を受ける以前の建物事前調查に着目し、この調査から得られる既 存建物の実態を示すデー夕を扱った。分析に用いたデータは、都内、 隅田.江東.足立.江戸川.葛飾区を中心にその近郊を含めた 113 地区で 調査を行った建物のうち、直接基礎の戸建て住宅で、沈下測定、建築 年等の分析に必要なデー夕を有する 864 棟（以下「調査デー夕」）を 対象とした。また、このうち基礎について鉄筋探査、形状、損傷状沉 など、の実態調查を行った 189 棟（以下「基礎調査データ」）のデー タを用いた。

\section{表-1. 建物事前調査項目}

\begin{tabular}{|c|l|}
\hline 規模構造 & 構造・階数・建築面積・延床面積・閒取り \\
\hline .建物仕様 & 屋根・外壁・基䃈形式・建築年・增改筑 \\
\hline 損傷調查 & 床沈下傾斜測定・柱傾斜測定・損傷状況 \\
\hline
\end{tabular}

\section{2-2. 分析方法}

住宅基礎の変遷は、(財)住宅金融公庫(以下、公庫)の仕様から概称 把握できる 2) 3)。表-2 は、1950 年以降の公庫仕様を示した。1982 年 には底盤の無い布基礎の削除、鉄筋コンクリート基礎の標準断面が記 載され、大幅な性能向上に改定がなされている。筆者らが行った前述 の基礎の実態調查 ${ }^{11}$ によれば、1982 年の改定後から有筋基礎の割合

表-2 住宅金融公庫融資住宅の基礎仕様例 2）3)

\begin{tabular}{|c|c|}
\hline 1950年 & 基礎はコンクリートのほかに煉瓦類、石積、ブロック積。 \\
\hline 1960年 & 無筋布基礎の標潐断面。幅 $12 \mathrm{~cm}$ 以上地盤面 $24 \mathrm{~cm}$ 以上根入れ $12 \mathrm{~cm}$ 以上。 \\
\hline 1962年 & 2階建住宅で底盤（幅 $32 \mathrm{~cm}$ 、厚さ $12 \mathrm{~cm} ）$ を設けた断面図の追加。 \\
\hline 1973年 & 石積及びブロック積の布基礎の仕様を廃止。 \\
\hline 1982年 & $\begin{array}{l}\text { 地盤調查の必要性、杭打ち地業の追加。底盤の無い布基礎を削除。立 } \\
\text { 上り高さ標準 } 30 \mathrm{~cm} \text { 。鉄筋コンクリート基礎断面と開口補強を図示。 }\end{array}$ \\
\hline 1985年 & 布基礎鉄筋の種類を異形鉄筋。隅角部の鉄筋による補強仕様の図示。 \\
\hline 1987年 & 高酎久性木造住宅割増融餈の新設に伴い特記仕様を追加。 \\
\hline 1988年 & $\begin{array}{l}\text { 「土間コンクリートと一体の布基礎」を「ベタ基礎と一体の布基礎」 } \\
\text { に。Fcを135 } 180 \mathrm{~kg} / \mathrm{cm}^{2} \text { に見直し。鉄筋の端部のフックの規定。 }\end{array}$ \\
\hline 1994年 & $\begin{array}{l}\text { 基礎天端の地盤面からの高さを「 } \\
\text { ると共に参考図を修正。 }\end{array}$ \\
\hline 1996 2000年 & 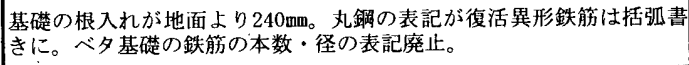 \\
\hline 2003年 & $\begin{array}{l}\text { 丸鋼の表記廃止。立上り標準高さが400m经変更。縌筋の下部定着を } \\
\text { 盤端部まで延長 }\end{array}$ \\
\hline
\end{tabular}

は多くなり、改定の効果が見られ、1985 年以降の建物の殆どは有筋 基礎となっている。図-1 にはこの実態調査による基礎断面形状と建 設省告示第 1347 号（以下「現行規定」）に規定される基礎仕様を比 較して示した。これによれば鉄筋径や根入れ長等不明な部分もあるが、 公庫仕様改定後の基礎は概站告示の仕様に近いと考えられる。このた め本研究では、調查デー夕について 1985 年以前(規定の改定は 1982 年であるが、改定内容の定着に数年を要すると考えられ、また上述し たように 1985 年以降ではほとんど有筋になっていたためここでは 1985 年前後で区別した)とそれ以降に分類してそれぞれの経年変化 の違いから基礎の耐用性について分析を行った。

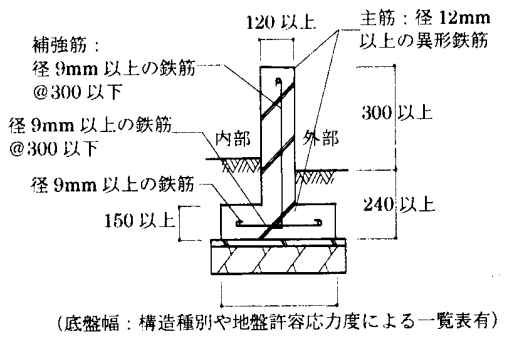

(a)建設省告示第 1347 号(平成 12 年)より

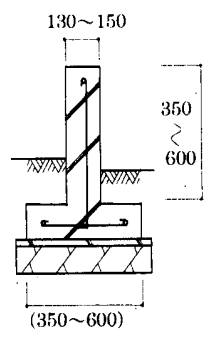

図-1＼cjkstart鉄筋コンクリート造布基礎参考図

2-3. 評価方法

既存住宅性能表示制度 4)（以下、「既存住宅制度」）は、新筑住宅を 除くすべての住宅で利用可能で、設計や施工に関する基本情報のほか に、現況検查（部位及び総合判定（必須）と特定検査（任意））に基 づく劣化等と新築住宅の性能表示とほぼ同等（但し選択性）の個別性 能の評価が表示対象になっている。一方、既存住宅保証制度 5)（以下 「既存保証制度」）は、筑 15 年以内の戸建住宅が対象であり、住宅 性能保証制度、住宅性能表示制度、住宅金融公庫融資、建築基準法の うち、いずれかに基づく公的な中間検査実施されていることと、住宅 履歴の申告と共に、現場検査により劣化状況等の程度が中古住宅登録 基準に適合しているかの確認が必要である。現場検查は先の既存住宅 制度における現況調查とほぼ同様である。

既存住宅制度の判定では、劣化程度が評洒基準に照らして詳細調査 又は補修を要する程度か否かで表示され、評価基準は、住宅紛争処理 の参考となるべき技術的基準として規定された建設省告示第 1653 号 で構造耐力上主要な部分に瑕疪が一定程度存するとされるレベル 2 の事象と概ね一致している。また、既存保証制度の登録基準には(1)既 存住宅保証部位別登録基準と(2)既存住宅保証防水補修基淮があり、こ の基準に示される劣化事象等が無いことが必要である。(2)の既存住宅 保証防水補修基準に関しては、外壁・屋根等について仕上げ材ごとの 防水工事方法が示され、雨水の浸入の防止をする部分について、この 防水工事が引渡前 3 年以内に実施されている場合、このメンテナンス 実施後 5 年間を、またその他は引渡後 2 年間を保証期間とすること になっている。なお、(1)の部位別登録基準は前述告示の構造耐力上主 要な部分に层疵が存する可能性が低いとされるレベル 1 の事象と概 ね一致している。 
表-3 には、既存住宅制度と既存保証制度の基礎に関する劣化現象 等の評価項目と評価方法の概要を示す。以降ではこれらの評価基準を 参考に評価レベルを設定して分析を行った。

\begin{tabular}{|c|c|c|c|}
\hline & 既存保証制度 & 既存住宅制度 & 左記基隻外 \\
\hline $\begin{array}{l}\text { 基礎・壁等 } \\
\text { コンクリー } \\
\text { ト直仕上部 }\end{array}$ & 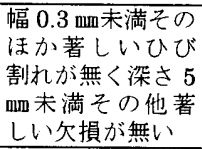 & $\begin{array}{l}\text { 幅 } 0.5 \mathrm{~mm} \text { 未満その } \\
\text { ほが著しいひび割 } \\
\text { れが無く深さ } 20 \\
\text { mm未満その他著し } \\
\text { い欠損が無い }\end{array}$ & $\begin{array}{l}\text { 幅 } 0.5 \mathrm{~mm} \text { 以上、著 } \\
\text { しいひび割れ } \\
\text { 深さ } 20 \mathrm{~mm} \text { m上そ } \\
\text { の他著しい欠損 }\end{array}$ \\
\hline $\begin{array}{l}\text { 基礎・壁等 } \\
\text { モルタル等 } \\
\text { 仕上部 }\end{array}$ & $\begin{array}{l}\text { 著しいひび割れ } \\
\text { 著しい欠損・浮 } \\
\text { き・剥がれが無い }\end{array}$ & $\begin{array}{l}\text { 著しいひび割れ著 } \\
\text { 剥がれが浮き無い }\end{array}$ & $\begin{array}{l}\text { 著しいひび割れ } \\
\text { 著しい欠損・浮 } \\
\text { き・剥がれれ }\end{array}$ \\
\hline $\begin{array}{l}\text { 壁・柱等の } \\
\text { 傾斜 }\end{array}$ & $\begin{array}{c}3 / 1000 \text { 末満 } \\
\text { の傾斜 }\end{array}$ & $\begin{array}{c}6 / 1000 \text { 末満 } \\
\text { の傾斜 }\end{array}$ & $\begin{array}{c}6 / 1000 \text { 以上 } \\
\text { の傾斜 }\end{array}$ \\
\hline $\begin{array}{l}\text { 居室の床の } \\
\text { 傾斜 } \\
\end{array}$ & $\begin{array}{c}3 / 1000 \text { 末满 } \\
\text { の傾斜 }\end{array}$ & $\begin{array}{c}6 / 1000 \text { 末満 } \\
\text { の傾斜 } \\
\end{array}$ & $\begin{array}{c}6 / 1000 \text { 以上 } \\
\text { の傾斜 }\end{array}$ \\
\hline $\begin{array}{l}\text { 告示 } 1653 \text { 号 } \\
\text { の相当する } \\
\text { レベル区分 } \\
\end{array}$ & レベル 1 & レベル 2 & レベル 3 \\
\hline $\begin{array}{l}\text { 本報での } \\
\text { 評価レベル }\end{array}$ & レベル II & レベル I & \\
\hline
\end{tabular}

既存住宅制度の評価基準 : 劣化程度「修復を要する」に至らないレベル 既存保証制度の評価基準：登録条件である「劣化が認められない」レベル

\section{3. 既存建物の実態調查分析}

\section{$3 \cdot 1$. 既存建物の調査データの概要}

調査データの概要を表-4、図-2 に示す。表-4 には構造規模別の割 合を示しており、木造系 $92 \%$ 、非木造系 $8 \%$ 、平屋 $6.7 \%$ 、2 階建 $90.9 \%$ 、 3 階建 $2.4 \%$ である。

図-2 には調査年と建築年と経過年数の件数分布を示す。建築年は $1975 \sim 1980$ 年、経過年数は $11 \sim 20$ 年の建物が最も多い。このうち 1985 年以降の建物は 167 件、全体の $19.2 \%$ で、その平均経過年数は 約 4 年である。調查時期は $1985 \sim 1995$ 年の 10 年間に及んでいる。 経過年数は建築から調查時点までであるので、築年と経過年数の分布 は一致しない。

表-4 構造階数区分（単位: 戸数）

\begin{tabular}{|c|c|c|c|c|}
\hline & 平屋 & 2階建 & 3階建 & 計 \\
\hline 木造系 & 55 & 738 & 2 & 795 \\
\hline 非木造系 & 3 & 47 & 19 & 69 \\
\hline 計 & 58 & 785 & 21 & 864 \\
\hline
\end{tabular}

経過年数区分(年)

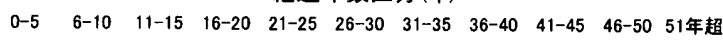

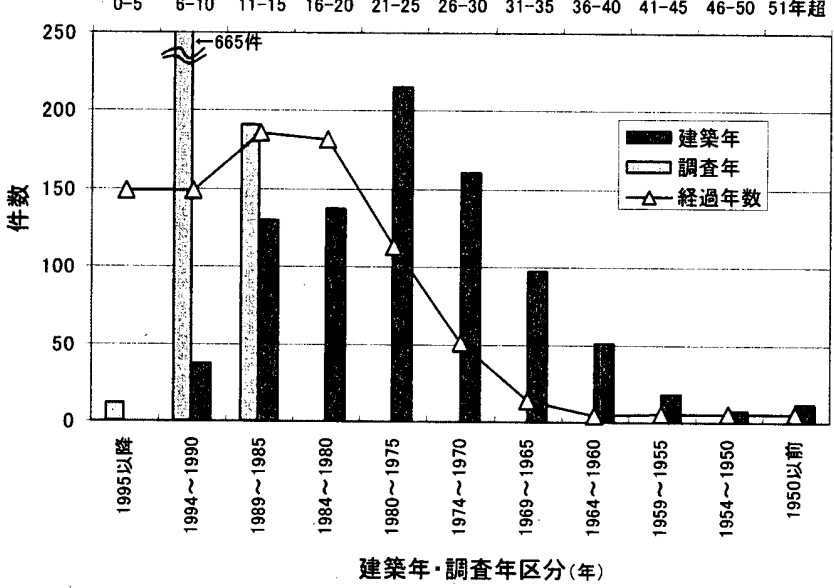

図-2＼cjkstart建築年と経過年数の分布

\section{3-2. 不同沈下量}

内部床面の水盛管による水平測定（写真·1）の結果から、不同沈下 の特徴を分析した。沈下量の定義は図-3 に示すとおりであり、各測 定䉪所のうち最大の不同沈下量を扱った。不同沈下量の許容値は、こ れまでの沈下障害の研究 ${ }^{6}$ によれば、木造住宅の布基礎において 25 mmを超えると急激に障害程度が大きくなることや、参考となる文献 7)などから、25mm 程度と考えられる。

図-4 には不同沈下量と建築年及び経過年数の関係を示した。不同 沈下量は、経過年数、建築年において各年とも0〜90 $\mathrm{mm}$ に分布し、 共に全体的に同様の分布傾向を示しているが、建築年で 1985 年以降、 経過年数で 10 年以下の範囲で、経過年数の分布の方だけに大きな沈 下量の発生が見られる。

このため図-5では、1985 年以降の建物と、それ以前の建物で同等 の経過年数である経過年数 10 年以内の建物について、不同沈下量の 発生率を比較して示した。1985 年以前の経過年数 10 年以下の建物 で $25 \mathrm{~mm}$ 超える割合は、26〜 $50 \mathrm{~mm}$ 以下の $16.7 \%$ と $50 \mathrm{~mm}$ 超の $3 \%$ を 加えた約 2 割である。1985 年以降の建物では $25 \mathrm{~mm}$ 超える割合は、 26〜50 m 以下の $8.4 \%$ と $50 \mathrm{~mm}$ 超の $1.2 \%$ を加えた約 1 割で、 $10 \mathrm{~mm}$ 下の割合は 5 割近くあるのに対して、それ以前の建物は 2 割強で両 者の違いは顕著である。以上のことから、公庫仕様の改定を契機とす る基礎仕様の向上は、建築後の不同沈下量の発生に対しても一定の抑 止効果につながっていると考えられる。
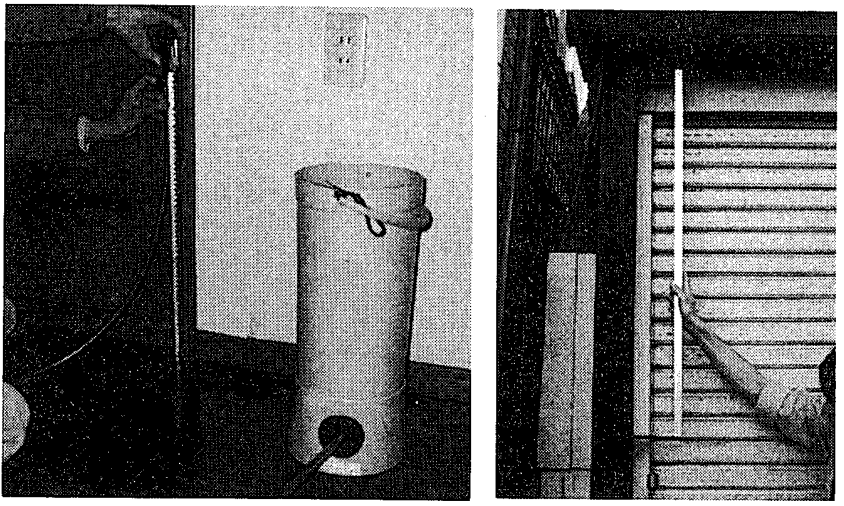

写真-1＼cjkstart水盛管による水平測定および柱傾斜の測定

傾斜角 $\mathrm{a}: \mathrm{BC}$ 間の沈下量 $(\alpha-\beta)$ 距離 $\mathrm{L} 1$ 傾斜角 $\mathrm{b}: \mathrm{AB}$ 間の沈下量 $(\beta)$ 距離 $\mathrm{L} 2$ 変形角 $\theta$ : 傾斜角 $\mathrm{a}$ 一傾斜角 $\mathrm{b}$

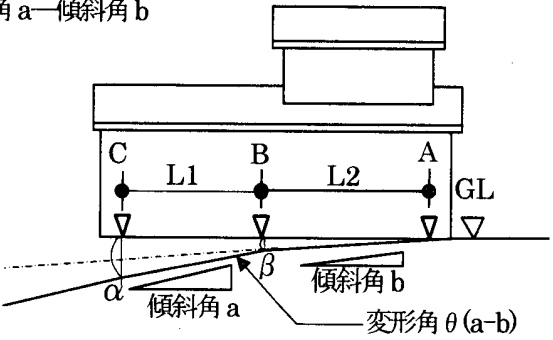

図-3 傾斜角と変形角の算出方法 


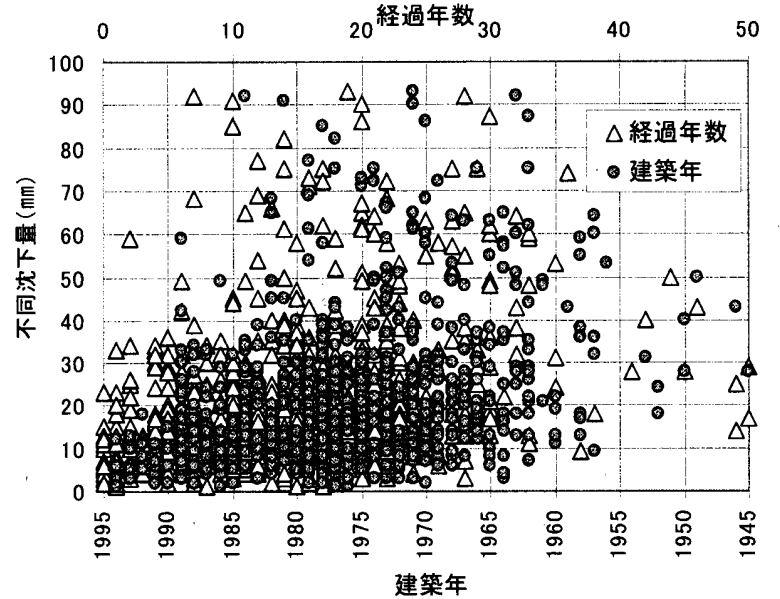

図-4＼cjkstart建築年と経過年数と不同沈下量

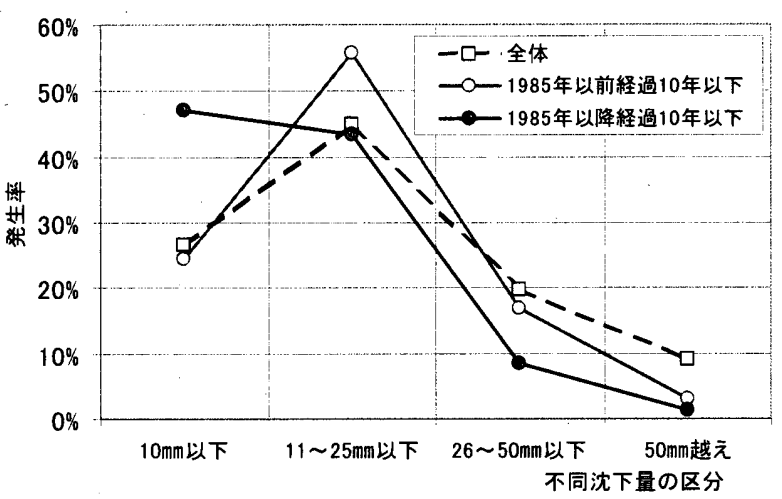

図-5 不同沈下量の発生割合

\section{3-3. 床の傾斜角}

床の傾斜角の評価に際しては、測定方法も重要であり、ここではま ず、建物全体の傾斜角（建物 4 隅など）と一定区間の傾斜角の関係を 示寸。

表-3 の評価基準における床の傾斜の必要な測定距離は、 $2.5 \mathrm{~m}$ 以上 (四捨五入して $3 \mathrm{~m}$ ） とされているため9)、測定される傾斜角（図-3 の A-B B-C の各区間傾斜角）は、建物全体の傾斜角（図-3の A C 間傾斜角）よりも大きな值を示す。図-6 は建物全体の傾斜角（全体 傾斜角）と最も大きな值を示した区間の傾斜角（最大傾斜角）を比較 したものであるが、全体傾斜角に比べて最大傾斜角は 2 割以上大きな 值を示すことがわかる。以後の検討は最大傾斜角を用いて分析を行っ た。なお、図中に示寸線形とは、最小自乗法を用いて求めた回帰式に よるデータの傾向を示す線で図-7〜9も全て同様である。

図-7は、1985 年以前と以降の建物の最大傾斜角と不同沈下量の関 係を示したものである。近接工事による不同沈下時のように端部が極 端に沈下する場合は、基礎仕様の違いにより不同沈下量と傾斜角の関 係には大きな違いが現れたが、外乱要因の影響を受けない今回の調査 データでは、基礎仕様による顕著な傾向は見られない。傾斜角は基礎 仕様よりもむしろ不同沈下量に支配的で、概ね不同沈下量(単位 $\mathrm{mm}$ ) の $(0.1 \sim 0.25) / 1000$ 程度の傾斜角が生ずるようである。既往の研究 ${ }^{8)}$ では不同沈下量に対して 0.1/1000 程度の全体傾斜角の発生が報告さ れており、最大傾斜角と全体傾斜角の関倸を考えれば良い対応を示し

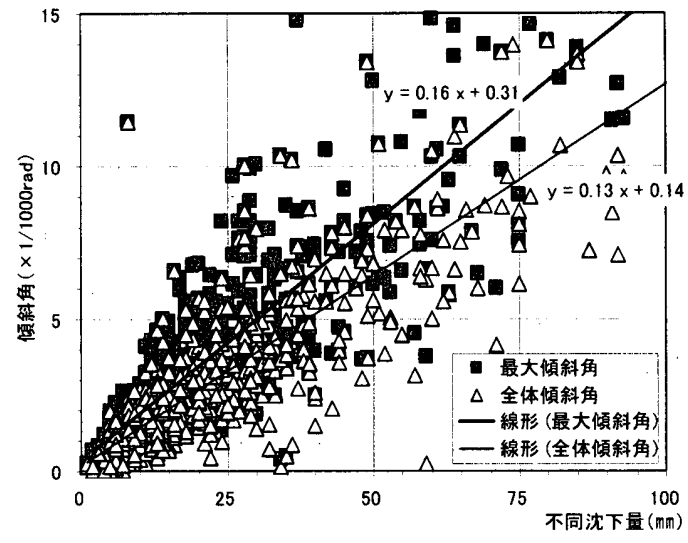

図-6 不同沈下量と傾斜角

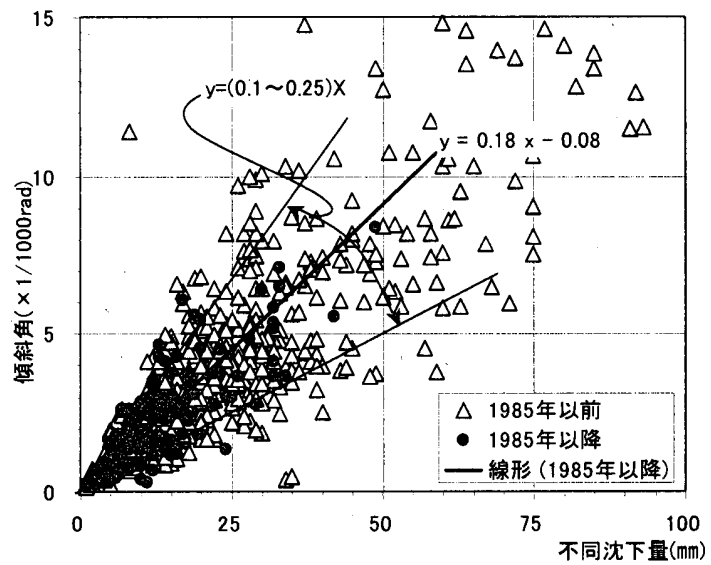

図-7＼cjkstart建築年区分の不同沈下量と傾斜角

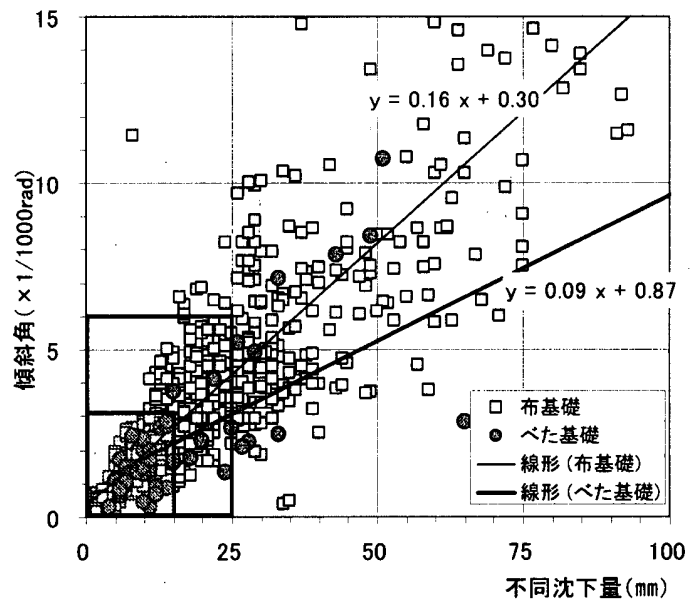

図-8＼cjkstart基礎形式による不同沈下量と傾斜角

表-5 傾斜角の発生率

\begin{tabular}{|c|c|c|c|c|c|c|}
\hline \multirow{3}{*}{$\frac{\text { 傾斜角区分 }}{1 / 1000 \text { 以下 }}$} & \multirow{2}{*}{\multicolumn{2}{|c|}{ 全件数 }} & \multicolumn{4}{|c|}{ 経過年数 10 年以下 } \\
\hline & & & \multicolumn{2}{|c|}{1985 年以前 } & \multicolumn{2}{|c|}{1985 年以降 } \\
\hline & 104 & $12.7 \%$ & 15 & $12.6 \%$ & 44 & $27.3 \%$ \\
\hline $1 \sim 3 / 1000$ & 352 & $43.0 \%$ & 63 & $52.9 \%$ & 86 & $53.4 \%$ \\
\hline $3 \sim 6 / 1000$ & 225 & $27.5 \%$ & 31 & $26.1 \%$ & 26 & $16.1 \%$ \\
\hline $6 / 1000$ 超え & 137 & $16.7 \%$ & 10 & $8.4 \%$ & 5 & $3.1 \%$ \\
\hline 計 & 818 & $100.0 \%$ & 119 & $100.0 \%$ & 161 & 100.0 \\
\hline
\end{tabular}


ている。また図-8 は、このうち布基礎とべた基礎の基礎形式別に不 同沈下量と傾斜角の発生を示したものである。布基礎では不同沈下量 の許容值 $25 \mathrm{~mm}$ 程度以下であれば、既存住宅制度の評価基準 $6 / 1000$ をほぼ満足するが、既存保証制度の登録基準である $3 / 1000$ を満足す るには不同沈下量が概ね $15 \mathrm{~mm}$ 以下であることが必要となる。べた 基礎はデー夕数の関係で偏りがあり明瞭ではないものの、布基礎に比 べて不同沈下量の発生に対して傾斜角発生の抑止効果が大きく、不同 沈下量が $25 \mathrm{~mm}$ 以下であれば傾斜角は概福 $3 / 1000$ 以下となっている。 表-5は 1985 年以前と以後の建物について傾斜角の発生割合を示し たものである。1985 年以後の建物では表示制度の評価基準 6/1000 を超える割合は非常に少なく、保証制度の登録基準である $3 / 1000$ 以 下を満足する建物は 8 割である。

\section{3-4. 柱傾斜}

以上は床の傾斜に着目した結果であるが、ここでは柱の傾斜と床 の傾斜の関倸について調べることにした。図・9にはその結果を示す。 前述の床の傾斜の分析の通り、傾斜角は不同沈下量に支配的であるこ とから、経年的な不同沈下現象は、建物が一体に沈下傾斜する剛体傾 斜に近いと考えられるが、図-9 の結果から判断すると、柱傾斜と床 傾斜の関倸は必ずしも $1: 1$ の関係を示していない。平均傾斜角は両 者で近い值を示寸が、柱の最大傾斜角は床のそれに比べて大きな傾向 を示し、ばらつきが大きい。床傾斜が見られない建物でも $2 / 1000$ 程 度の柱傾斜が見られることは、施工精度の影響や金具等の接合部の剛 性の影響も考えられる。建方精度に関する調査 10にによれば、建方作 業後の柱の傾斜の平均值は、プレカット材で $2.28 / 1000$ 手刻み材で 2.72/1000 であり、今回の結果は従前の報告とも一致している。

建築時のばらつきを含め最大值を考えた場合、床傾斜の $2 / 1000$ 及

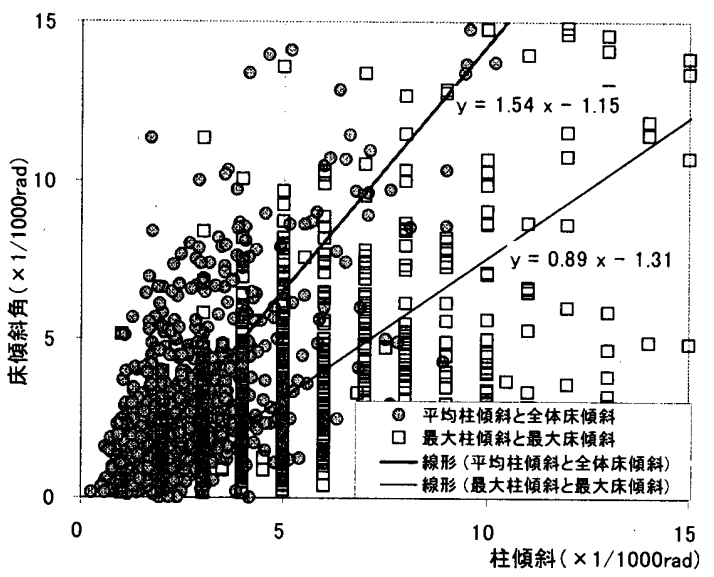

図-9＼cjkstart床と柱傾斜角の関倸

表-6 柱傾斜角の発生率

\begin{tabular}{|c|c|c|c|c|c|c|}
\hline \multirow{3}{*}{$\frac{\text { 傾斜角区分 }}{1 / 1000 \text { 以下 }}$} & \multirow{2}{*}{\multicolumn{2}{|c|}{ 全件数 }} & \multicolumn{4}{|c|}{ 経過年数 10 年以内 } \\
\hline & & & \multicolumn{2}{|c|}{1985 年以前 } & \multicolumn{2}{|c|}{1985 年以降 } \\
\hline & 6 & $0.7 \%$ & 0 & $0.0 \%$ & 4 & $2.4 \%$ \\
\hline $1 \sim 3 / 1000$ & 139 & $16.2 \%$ & 20 & $15.4 \%$ & 64 & $38.6 \%$ \\
\hline $3 \sim 6 / 1000$ & 479 & $55.8 \%$ & 86 & $66.2 \%$ & 86 & $51.8 \%$ \\
\hline 6/1000 超え & 234 & $27.3 \%$ & 24. & $18.5 \%$ & 12 & $7.2 \%$ \\
\hline 計 & 858 & $100.0 \%$ & 130 & $100.0 \%$ & 166 & $100.0 \%$ \\
\hline
\end{tabular}

び 4/1000、不同沈下量では $10 \mathrm{~mm}$ 及び $20 \mathrm{~mm}$ 程度以上の沈下傾斜が生 じると柱傾斜 $3 / 1000$ 及び $6 / 1000$ を超えると考えられる。

\section{3-5. 基礎のひび割れ}

写真-2には基礎ひび割れの様子を、図-10には基礎の平均ひび割れ 幅と不同沈下量及び傾斜角の関係を示す。基礎のひび割れは建物外周 部でスケールを用いて目視調査により測定し、建物ごとの平均幅を少 ンプルデータとした。この結果、本データの範囲では基礎のひび割れ の度合いと不同沈下量及び傾斜角との間に明瞭な関倸は見出せなか った。不同沈下による基礎のひび割れは不同沈下量の傾斜角でなく変 形角が原因となり発生する。また、収縮ひび割れも不同沈下量・傾斜 角に関係無く発生する。前述の通り、近接工事による不同沈下では、 短期的に単部が沈下するため沈下量とひび割れとの関倸が明らかで あったが、経年的に生ずる不同沈下では沈下形状が様々であり、不同 沈下量や傾斜角では変形角の発生状況を表せていないためと考えら れる。表-7は 1985 年以前と以後の建物について、ひび割れ幅の発生 割合を示したものである。1985 年以後の建物では $0.5 \mathrm{~mm}$ 超えるひ
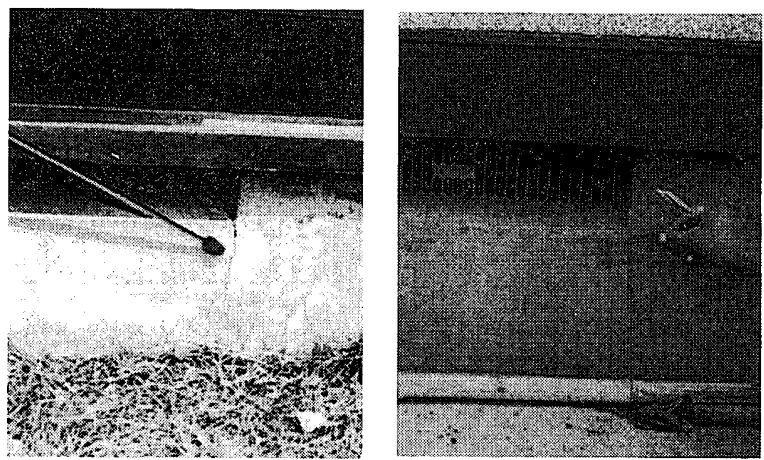

写真-2 基礎のひび割れ状況

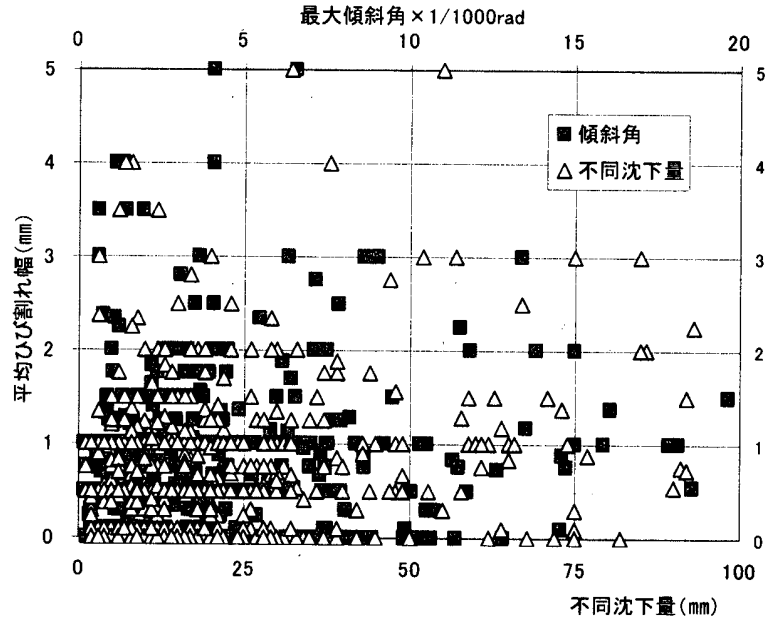

図-10 不同沈下量・傾斜角と基礎のひび割れ

表-7 基䃈ひび割れの発生率

\begin{tabular}{|c|r|r|r|r|r|r|}
\hline \multirow{2}{*}{ 傾斜角区分 } & \multicolumn{2}{|c|}{ 全件数 } & \multicolumn{3}{|c|}{ 経過年数10年以内 } \\
\cline { 3 - 7 } & & \multicolumn{2}{|c|}{1985 年以前 } & \multicolumn{2}{|c|}{1985 年以降 } \\
\hline ひび割れ無し & 148 & $24.20 \%$ & 24 & $23.10 \%$ & 47 & $35.60 \%$ \\
\hline 0.5 以下 & 188 & $30.80 \%$ & 33 & $31.70 \%$ & 55 & $41.70 \%$ \\
\hline $0.5 \sim 1.0$ 以下 & 142 & $23.20 \%$ & 25 & $24.00 \%$ & 26 & $19.70 \%$ \\
\hline 1 以上 & 133 & $21.80 \%$ & 22 & $21.20 \%$ & 4 & $3.00 \%$ \\
\hline 計 & 611 & $100.00 \%$ & 104 & $100.00 \%$ & 132 & $100.00 \%$ \\
\hline
\end{tabular}


び割れ幅の発生は 2 割程度であり、1985 年以前の 5 割弱に比べて半 分程度となっている。以上より、基礎のひびわれについては、不同沈 下よりもむしろ建物の経過年数や基礎仕様との関連性が強いようで ある。

\section{4.まとめ}

戸建住宅の基礎の分野では、沈下障害などのトラブルが、法令改正 や居住者意識の向上に伴い増加している。このため、基礎の耐用性に 関する数多くのデータを収集分析し、住宅の使用性や機能に支障のな い範囲の意味を明確にし、それに対応した基礎の設計施工技術を構築 することが重要である。

現状の既存住宅表示制度や保証制度を考慮すると、耐用性能のレべ ル・区分としては、(1)既存住宅表示制度で補修を要すると判断されな い 6/1000 以上の傾斜や $0.5 \mathrm{~mm}$ 以上のひび割れの発生が生じないレべ ル（以下「評価レベルI」)。(2)保証制度で保証登録が可能な $3 / 1000$ 以上の傾斜や $0.3 \mathrm{~mm}$ 以上のひび割れの発生が建築後 15 年以内に生じ ないレベル（以下「評価レベルＩI」）などが考えられ、今回の調査住 宅に上記のレベルを適用した結果をまとめると以下のようになる。

1. 住宅金融公庫の標準基礎仕様において 1982 年の改定（底盤の無 い布基礎の削除、鉄筋コンクリート基礎の標準断面の記載）は抜 本的なものであり、今回の調査結果から判断すると、改定に伴っ て鉄筋コンクリートの基礎が標準的なものになった頃を境に、建 築後 10 年間の不同沈下量が従前と比較すると抑制されており、 改定の効果があったと考えられる。しかし、不同沈下量の許容値 を $25 \mathrm{~mm}$ と考えた場合、軟弱地盤地域ではこれを超えるケースも 1割程度は見られる事から基礎仕様だけの対策では必ずしも十分 とは言えない。

2. 床の傾斜角は不同沈下量に密接にかかわっており、べた基礎であ れば不同沈下量 $25 \mathrm{~mm}$ 以下であれば評価レベルாを満足している。 一方、布基礎では、不同沈下量 25 mm以下であれば評価レベル I を満足するが、評価レベル II を満足するには不同沈下量 $15 \mathrm{~mm}$ 下となっている。実態調査でも評価レベル II を超える建物は 2 割 近くに及ぶ。

3. 柱傾斜は床の傾斜が見られない建物でも $2 / 1000$ 程度の傾斜が見 られ、ばらつきが大きいものの総体的に床傾斜よりも大きな值を 示す。評価レベル Iを満足する建物は約 9 割を超えるが、評価レ ベル II を満足する建物は 4 割程度である。

4. 基礎のひび割れに関しては 2 割以上の建物で評価レベル I を超え

る。

なお、今回の調查は、東京下町を中心とした軟弱地盤地域であり、 必ずしも全体の傾向を表すものではないことに留意しなければなら ない。また、今回の調查住宅は、平成 12 年建設省告示第 1347 号や 平成 13 年国土交通省告示第 1113 号において住宅基礎に倸わる数多 くの規定 '(例えば、基礎の寸法・配筋等に関する最低基準やスウェー デン式サウンデングによる地盤の許容支持力算定式の新設とそれに 基づく軟弱地盤での沈下の検討の必要性の明確化) が出される以前の 住宅であり、調査結果を現在建設されている新規の住宅にそのまま当 てはめることは適切でない。今後、さらにデータを蓄積し、沈下障害
と基礎仕様の関係などを検討する予定である。特に最近軟弱地盤では 沈下対策としての地盤改良工法を採用寸ることが増えているが、改良 地盤上の沈下障害の報告も少なくないので、地盤改良の方法や改良仕 様、地盤条件なども加味した改良地盤上の住宅基礎の耐用性の実態調 查を行い、地盤改良の効果を検証することが今後特に重要である。

参考文献

1）田村昌仁・伊奈潔・藤井衛，近接掘削工事に起因寸る户建住宅の 基礎の障害について, 日本建築学会構造系論文集, 第 556 号, pp85-91, 2002.6

2）木造住宅工事共通仕様書平成 15 年改訂，(財) 住宅金融普及協会

3）田村昌仁 - 藤井衛 - 河合直人 ・植田静喜, 戸建住宅を対象とした 基礎・地盤の性能評価の考え方, 土と基礎, Vol.49.№.4, pp.4-7, 2001.4

4）既存住宅の住宅性能表示制度ガイド, 国土交通省 住宅局住宅生 産課

5）例えば （財）住宅保証機構, http://www.ohw.or.jpl, 既存住宅保 証制度の紹介

6）伊奈潔・田村昌仁・藤井衛，掘削工事による近接住宅の被害予測, 第 38 回地盤工学研究発表会, pp1581・1582, 2003.7

7）建築基礎構造設計指針，日本建築学会，2001.10

8）芳賀保夫，木造建物の不同沈下と障害，土と基礎，Vol.41.No.11, pp59-64, 1993.11

9) 平成 12 年度版住宅紛争処理技術関連資料集, (財) 住宅リフォー ム・紛争処理支援センター, 2000.9

10）檠沼法彦・茶谷正洋・八木幸二・石川清・山畑信博, 木造在来軸 組構法による戸建住宅の建方精度と合理化に関する研究 その 2 建方作業と柱の倒れ, 日本建築学会大会学術講演梗概集, pp897 $\sim 898, \quad 1991.9$

11）構築物の耐用性診断とその対策, 耐用性研究会編著, 彰国社, 1976.5 